\title{
Research on the Service Quality of China's Inspection and Certification Institutions
}

\author{
Mingjie $\mathrm{Hu}^{1}$, Guangcheng $\mathrm{Xu}^{1}$, Zhaoying Zuo ${ }^{1,2}$, a, ${ }^{*}$, Xiangwei Yin ${ }^{1}$, Wei $\operatorname{Tian}^{1}$, \\ Xiaodan $\mathrm{Yang}^{1}, \mathrm{Na} \mathrm{Li}^{1}$ \\ ${ }^{1}$ Rizhao Inspection \&Certification Company, Rizhao 276800, China \\ ${ }^{2}$ Business School, Hohai University, Nanjing 211100, China \\ *, a 836594289@qq.com
}

Keywords: inspection and certification; service quality; high-tech industries.

\begin{abstract}
The paper discusses how certification institutions improve service quality. Inspection and certification institutions should pay attention to brand construction, make full use of information and big data, improve the business staff' level and skill, and shape adaptive service culture and strengthen the interface management which is an important reference for improving the service quality of China's inspection and certification institutions. Also, the paper has great value for promoting the development of China's high-tech industries.
\end{abstract}

\section{Introduction}

The investigation results of "2017 China's Foreign Trade Service Market Research Report" show that in rankings of the most reliable inspection and certification institutions of foreign trade enterprise in 2017, the Swiss SGS continue to top in this list and occupies the top for long, the second is Germany TÜV Rhein land Group, American UL and UK Intertek Group. The quality certification center of native China only is 6th. According to the repot of "Economic Information Daily" on October 10, 2017, more and more countries or receiving traders require foreign capital inspection and certification institutions to issue relevant certificates and even as exchange settlement voucher, export commodity inspection and certification market has been monopolized by foreign institutions to some degree, according to the investigation of Ningbo certification and accreditation association, foreign institutions occupy more than $85 \%$ of market share in Ningbo import and export inspection and certification. Certification and Accreditation Administration of the People's Republic of China reported on September 11, 2017 that 25 registry staff renewed verification experience and defrauded the qualifications of the registry staff in one Shanghai certification institution, including the company's major shareholders; and the rampant degree was simply startling. At the end of 2016, China's accumulatively issued more than 1768000 effective certification certificates, more than 597000 inspection and certification institutions, ranked the world's first for many years, the total revenue of inspection and certification services business reached 200 billion Yuan, and become the world's fastest growing inspection and certification market. Inspection and certification industry is the high technology service which state encourages its development, 2016 "13th five-year plan" national strategic emerging industry development planning listed the certification industry in the national strategic emerging industry, and certification and accreditation is an important part of national quality infrastructure (NQI). Today, as the economic progress entering the "new normal" and comprehensively deepening the reform, improving the service quality of inspection and certification institutions is the inevitable choice for innovative development and standardize competition of certification institutions and it is also the integral requirement of the inspection and certification industry to adapt to the supply-side reform. 


\section{Research Status at Home and Abroad}

Dogui K, Boiral O \& Heras-Saizarbitoria I (2013) studied the effect of the impartiality of the certification institutions which certification enterprises charge the assessment fee from the enterprise. Psomas, E. (2013) discussed the role of quality certification in service enterprises. Zhang X, and Xu, J. (2012) thought that, with the opening up of China, world renowned certification institutions such as SGS, UL, BSI and so on have set up affiliated agencies in China in succession, along with the increasingly harsh requirements of the customer, the competition among certification institutions is fierce, certification institutions need to improve the service quality service efficiency and other aspects, and optimization model of dispatch of internal auditors in certification institutions is established. Liu R, Cui L \& Zeng G et al. (2015) divided the service quality of inspection and certification institutions into empathy, tangibility, responsiveness, assurance, effectiveness and other indexes, and obtained this group's service quality and proposed improvement measures through the investigation of service client of China Certification \& Inspection (Group) Co., Ltd. Castka P (2015) et al. studied the relationship between enterprises' choice of certification institutions and enterprises' satisfaction. Zhang Y et al. (2017) discussed the state's regulatory measures on inspection institutions with dynamic evolutionary game theory. Zuo Zet al. (2017) studied the effect mechanism of certification institutions on enterprise performance.There few studies on the improvement of service quality of inspection and certification institutions, this paper attempts to fill this gap.

\section{The Promotion Strategy of Service Quality of Inspection and Certification Institutions in China}

First, service marketing should be vigorously developed. The essence of enterprise is innovation and marketing and it shows how important the marketing is. Because the activity of inspection and certification institutions is a service, which has imperceptibility, inseparability, diversity, non-storability and lack of ownership and so on, the characteristics of the service product decided the service marketing and the physical products marketing have different characteristics. The marketing must be carried out from tangibility, reliability, assurance, responsiveness and empathy of service; show the strength of the inspection and certification institutions, explore customers' needs and expectations, convey the customer's needs and expectations to the business staff, and organize the corresponding audit team after review. The valuable key customers are classified and managed, comprehensively use Internet marketing, knowledge marketing and other means, and enhance the overall marketing ability of the brand around brand loyalty. After the completion of the business and carry out return visit, pay attention to the enterprises' opinions and suggestions, deal with the complaints of enterprises timely, and communicate with the enterprises on the handling results. Because the service industry's characteristics cause customer stickiness of the service industry to be low, the loyalty is low, so do inspection and certification industry, so customer satisfaction is crucial.

Secondly, inspection and certification institutions should focus on brand building. The brand is the embodiment of the culture and core value of the inspection and certification institutions, which can bring the differentiation competitive advantage to the inspection and certification institutions; and it's the precious intangible asset of the inspection and certification institutions. Developing brand development strategy is the necessary requirement of the mature and development of the modern inspection and certification institutions, in the top-level design, it is necessary from enhancing brand awareness, perfecting brand human resources, improving the organizational structure of brand management, perfecting the rules and regulations of brand and so on to establish perfect brand strategy implementation system; in crisis management aspect, and register trademark at home and abroad in time to prevent rush registration, perfect the anti-counterfeiting measures of certificate report, moderately develop certificate anti-counterfeiting work, maintain the brand reputation, enhance brand crisis consciousness, establish crisis management team, timely, forcefully and appropriately solve the incidents which undermine brand reputation, and protect the authority and reputation of the brand. In the aspect of social responsibility, the inspection and certification science 
popularization education, volunteer service and other activities are carried out, actively shape and perform the image of social responsibility and form the brand scale effect. The establishment of the brand also needs to build the talents training and the introduction strategy. Human resource is the foundation of service innovation, the certification industry needs high-density knowledge and high-quality labor input, and it needs professional talents with high quality and skills. First, we should vigorously develop the "special talents", namely high-grade talents, and make them to be leader, example and model of the team. Second, we should focus on the development of "universal genius", namely the compound talents which are good at many things and expert in one and adapt to the new situation and new requirements of the expanding business. Third, we need to create a good atmosphere of worshiping, loving, using, leaving and nurturing talents.

Thirdly, information and big data should be made use of. Through the market research report of inspection and certification, customer appreciation and so on, form a cohesive relationship with enterprise customers, and it is an indispensable part to check service quality of the inspection and certification institutions. Market developers of inspection and certification institutions, first-line personnel' ability and quality affect the validity of inspection and certification. We need to accelerate the use of the Internet, cloud computing and big data, and provide more convenient, timely and thoughtful service. Learn from Baidu Know, good search and answer and other interactive knowledge and answer sharing platform operation mode. Learning from Baidu know, good search, questions and answers, and other interactive knowledge answer sharing platform operation mode, build inspection and certification business knowledge interaction and sharing community, initiatively face target customer and push policy direction through the official WeChat of the certification institutions, the best practice and other dynamic information, meanwhile actively collect the customer's opinion and suggestions on certification and accreditation, and strengthen the information interaction. For example, the business acceptance, certificate issue, inquiry of certificate qualification all can use Internet technology. When certification, remote electronic examination can be studied, the remote electronic examination has many characteristics, such as save time cost, improve efficiency compared with the traditional examination, big data technology is used, certification institutions can monitor the factory inspection in real time; control the timeliness from supervision after the event to the early warning, at the same time, various kinds of examination findings and examination basis are horizontally and vertically compared, find problems in the examination process in time.

Fourthly, inspection and certification institutions should improve the business staff level and skill. The inspection and certification institution are a typical knowledge-intensive service, which is the main source of information and knowledge, and provides intermediary services for clients through the use of professional knowledge. Unlike $\mathrm{T}$ the traditional manufacturing and service industries which need large funds, equipment and other tangible assets, knowledge, intelligence, research and development these intangible assets investment mainly play a decisive role in the inspection and certification institutions. As the implementation subject of the inspection and certification service, business staffs are in close contact with customers, they need to grasp the needs and changes of the industry the first time, give full play to professional technical advantages and improve service quality. In order to improve the customer's perceived service quality, enterprises that provide service for customers with face-to-face contact, they should improve service staff' skills to the maximum extent. Inspection and certification work is face-to-face contact work to a large extent. For example, many enterprise senior will be more actively communicate with auditors on management bottleneck, market competition and other issues in the certification process, they wish to further promote the standardization of management through the quality management system, if auditors cannot raise key problems or cannot deeply communicate with enterprise senior, enterprises may be required to change auditors or change institutions, the needs of customers is a big challenge on the auditor's professional competence. Inspection and certification institutions should establish a set of effective business staff' quality and ability management system, implement effective management for staff from recruitment and pre-work evaluation, training, performance review, rewards and punishment, promotion and other links, pay attention to the construction of learning-oriented enterprises, train the concept of knowledge sharing type, continuously strengthen staffs' professional knowledge, ability 
and quality training, often carry out technical discussion, understand, master and grasp industry cutting-edge technology. Certification institutions should establish the auditors' evaluation standard; evaluation standard is not that people have much knowledge but create much new and useful knowledge for enterprise communications, encourage staffs and others to share their knowledge, thus making knowledge play the maximum value.

Fifthly, inspection and certification institutions should build adaptive service culture. According to the strategic framework of "service triangle", the inspection and certification institution, enterprises and inspection and certification staff three key groups provide services together. Internal marketing is crucial, and a lot of evidences show that it's hard to achieve customer' satisfaction if service staff don't feel happy in work. Enterprises should create a relaxed, open and free communication service culture, provide staffs with creative thinking environment and encourage staff to maximize their own value. It is necessary to establish introduction mechanism of high-level talent and intelligence resources, rely on the social resources and power, the cooperation in running schools, directional training and many forms deepen the talent training mode of inspection and certification institutions, promote the inspection and certification institutions business staff and management personnel' evaluation mechanism reform, introduce equity, options and various incentive mode, form the distribution incentive mechanism of talent "gain both fame and wealth", enhance the inspection and certification institutions through the improvement of capabilities and incentives for talents. Enhance development and research of inspection and certification technology in military and civilian integration, the "big airplane" project, intelligent robot and national information security and other important areas; increase the rewards for innovative talents which has breakthroughs and innovations in basic research, application research and so on, study key technologies for marine wind power certification, key technologies of bioenergy certification, related products and materials verification technologies of new energy vehicle, solar energy products, system evaluation technologies and other prospective technology assessment, and make enterprise staff Increase the value.

Sixthly, the interface management should be strengthened. First of all, the internal interface management is enhanced. Because the form of project group is often taken in the inspection and certification process, the inspection and certification staffs temporarily form a project team, with the completion of the project, the activities of this team will be concluded. In order to improve the sensitivity of knowledge and information of salesman, professional vision will reduce the sensitivity of knowledge, on the one hand, lack of interest in each other's information, on the other hand, because the limitations of knowledge horizon cannot be felt, the salesman should cultivate the habit of systematic thinking, view each other's role and mutual influence systematically.

At the same time, the "groove and convex principle" can be considered in the task arrangement. Different business staffs have both boundary and fuzzy boundary in the knowledge aspect of and provide support and guarantee for the quick and good implementation of the audit project. Secondly, pay attention to the external interface management. For the inspection and certification work, the salesman represents the certification and inspection institution, and guide and participant represent the enterprises, because the communication is not in place, the two are prone to conflict, do return visit well to the representative of the enterprise, service remedy measures should be taken for customers' dissatisfaction.

\section{Conclusion}

The paper discusses how certification institutions improve service quality from vigorously carrying out service marketing, inspection and certification institutions should pay attention to brand construction, make full use of information and big data, improve the business staff level and skill six aspects, which is an important reference for improving the service quality of China's certification institutions, and it has certain reference value for promoting the development of China's high-tech industries, with the deepening of the Belt and Road of China, how to get better mutual recognition of China's inspection and certification brands is the future research direction 


\section{References}

[1]. Dogui K, Boiral O, Heras-Saizarbitoria I. Audit Fees and Auditor Independence: The Case of ISO 14001 Certification[J]. International Journal of Auditing, 2013, 18(1):14-26.

[2]. Psomas, E. The effectiveness of the ISO 9001 quality management system in service companies [J]. Total Quality Management\& Business Excellence Journal, 2013, 24(7-8): 769-781.

[3]. Zhang X, Xu J. Cost optimization of heterogeneous auditor's allocation in certification body[C]// International Conference on Service Systems and Service Management. IEEE, 2012:765-769.

[4]. Liu R, Cui L, Zeng G, et al. Applying the fuzzy SERVQUAL method to measure the service quality in certification \& inspection industry[J]. Applied Soft Computing, 2014, 26:508-512

[5]. Castka P, Prajogo D, Sohal A, et al. Understanding Frms' Selection of their ISO 9000 Third-party Certifiers[J], International Journal of Production Economics, 2015,162:125-133

[6]. Zhang Y., Wang Y., Zuo Z., 2017, Research on the Evolution Game of National Supervision on Inspection Body, Revista de la Facultad de Ingeniería,32(8),182-188.

[7]. Zuo Z., Tang D., Research on the Impact of ISO9001 Certification Effectiveness on Organizational Performance in China, Boletin tecnico/Technical Bulletin, 2017,55(4), 644-655.

[8]. Jian S, Yuesheng Z, Zhaoying Z et al., Research on the effectiveness improvement strategy of quality management system of chemical enterprises $[\mathrm{J}]$, Chemical Engineering Transactions, 2017,62, 1603-1608

[9]. Zuo Z., Wu S., Xu G., Evaluation of ISO9001 implementation effectiveness based on AHP-FUZZY comprehensive evaluation method [J], Boletin Tecnico/Technical Bulletin, 2017,55(70), 354-366. 